\title{
ENVIRONMENTAL AND SOCIAL IMPACT ASSESSMENT PROCEDURAL STEPS THAT UNDERPIN CONFLICT IDENTIFICATION: REFERENCE TO RENEWABLE ENERGY RESOURCE DEVELOPMENT IN KENYA
}

\author{
PHILIP M. OMENGE ${ }^{1}$, GILBERT O. OBWOYERE ${ }^{1}$, GEORGE W. ESHIAMWATA ${ }^{2}$, \\ STANLEY M. MAKINDI ${ }^{3} \&$ JATIN NATHWANI ${ }^{4}$ \\ ${ }^{1}$ Egerton University, Kenya \\ ${ }^{2}$ The Kenya National Commission for UNESCO, Kenya \\ ${ }^{3}$ Machakos University, Kenya \\ ${ }^{4}$ Waterloo Institute for Sustainable Energy University of Waterloo Canada
}

\begin{abstract}
Environmental and Social Impact Assessment (ESIA) is a tool for an integrated assessment of multifaceted impacts of a proposed project. ESIA can identify areas of potential conflicts and prevent conflicts from occurring early through appropriate mitigation measures. This notwithstanding, conflicts and public opposition arising from implementation of proposed projects which have been subjected to ESIA have been observed in various sectors in different countries and jurisdictions. Kenya is one of the African countries endowed with substantial renewable energy resources including geothermal, wind and solar energy resources. The country is now scaling up the development and utilization of these resources to meet growing energy demand. However, implementation of environmental procedures mainstreamed in the development of renewable energy resources, if inappropriately applied, has the potential to slow down development and exploitation trajectory of these resources. While all proposed renewable energy projects are subjected to the ESIA process, in some instances challenges have emerged at implementation resulting in conflicts that could be avoided. There is a clear need to understand, empirically, which of the ESIA procedural steps is critical in underpinning conflict identification for appropriate application. To determine how each of the ESIA procedural steps is likely to influence conflict identification, a statistical analysis was carried out for ESIA procedures based on questionnaire survey responses from sampled ESIA practitioners in Kenya. This article presents findings on the effect of ESIA procedural steps in conflict identification using cumulative odds ordinal logistic regression with proportional odds. Results show that the overall effect (on the dependent variable conflict identification) of the variables, public participation and monitoring is statically significant, $\chi^{2}(2)=9.12, p=0.01$ and $\chi^{2}(2)=6.29, p=0.04$, respectively. Further, the exponential of the $\log$ odds of the slope coefficients indicate that the independent variables public participation, decision making, project implementation and monitoring are statistically significant $\left[\chi^{2}(1)=9.12, p=0.00\right.$; $\chi^{2}(1)=4.04, p=0.04 ; \chi^{2}(1)=3.64, p=0.05$ and $\chi^{2}(1)=3.31, p=0.00$, respectively]. That is to say these independent variables have a statistically significant effect on the dependent variable conflict identification.
\end{abstract}

Keywords: conflict identification, decision making, Environmental and Social Impact Assessment, monitoring, public participation, renewable energy resources.

\section{BACKGROUND}

\subsection{Introduction}

Renewable energy resources play a role in mitigating climate change while providing reliable, affordable and clean energy [1]. It is estimated that renewable energy resources supply $14 \%$ of the global energy demand [2]. By the year 2100, it is projected that renewable energy resources will supply up to $80 \%$ of global energy demand [3]. This is vital in the access to 
affordable, reliable and clean energy as energy access is a powerful multiplier of all Sustainable Development Goals [4]. Whereas energy generation and transmission affects the environment, renewable energy sources could solve many environmental and social problems associated with non-renewable energy sources [5].

The development and use of renewable energy resources can, among other benefits, contribute to reducing local and global environmental impacts [6]. Energy developed from renewable sources is clean, more likely to be affordable and accessible. Increased access to clean, affordable and reliable energy is transformative especially to those living in extreme poverty [7]. Kenya has made remarkable progress in tapping the country's vast renewable energy resources to generate electricity [8-10]. Previously, unexploited geothermal, wind and solar resources are being developed for the country's energy mix [8]. Official government statistics indicate total installed electrical energy capacity to have risen from 1267.9 MW in the year 2008 to 2339.9 MW in the year 2017 [11]. In the period 2009-2018, Kenya's installed wind energy capacity rose from 0 to $336 \mathrm{MW}$, that of solar from 0 to $93 \mathrm{MW}$ while that of geothermal 163 to $663 \mathrm{MW}$ [12]. As of the year 2018, Kenya contributed $4.46 \%$ of Africa's total renewable energy installed capacity and $0.085 \%$ of the global renewable energy installed capacity [12].

The impressive statistics notwithstanding, Kenya has barely scratched the surface in the quest to exploit her renewable energy potential. Kenya is the first country in Africa to tap geothermal resource for energy [13]. The country's geothermal potential is between 7,000 and 10,000 MW [14], solar insolation level is between 4 and $6 \mathrm{kWh} / \mathrm{m}^{2} /$ day and peak insolation hours lasting up to 5-7 h [14-15]. Seventy-three per cent of total area of Kenya experiences annual mean wind speeds more than $6 \mathrm{~m} / \mathrm{s}$ at $100 \mathrm{~m}$ above ground, an immense potential for wind energy utilization [16]. Kenya has recorded significant milestone in the quest to exploit these vast renewable energy resources in the county. In 2019, Kenya launched a $50 \mathrm{MW}$ solar power plant, East Africa's largest on-grid solar powered plant located in Garisa part of North-Eastern Kenya [17] and $310 \mathrm{MW}$ wind farm, Africa's largest grid connected wind farm located at Turkana wind corridor in Loiyangalani, Marsabit County [18].

While acknowledging milestones so far achieved, Kenya is aware of challenges that need to be continuously addressed to avert potential setbacks when exploiting these resources as documented in some of the countries' national policies. The National Energy Policy of Kenya documents that 'the discovery of various natural resources in the country particularly those related to energy sector such as geothermal, oil, gas and coal has resulted in high expectations, confrontations and conflicts among communities where these resources have been discovered' [19]. More importantly, 'potential conflicts and social unrest associated with exploitation of these resources can cause costly delays to projects and operations' and that 'in some cases, these situations can lead to loss of lives and livelihoods among local populations, employees or contractors, and bring about profound developmental set-backs' [19]. Environmental and Social Impact Assessment (ESIA) is an important tool to help conflict identification and prevention [20]. If appropriately applied, it can prevent the conflicts from occurring by spelling out appropriate mitigation measures [21]. Part of the requirements during the development of renewable energy resources in Kenya is compliance to environmental legislations [19].

The compliance partly 'entails assessment of energy projects for their environmental, health and safety impacts in order to facilitate the establishment of mitigating measures and monitoring plans in parallel with energy development and consumption' [22]. Through this, 'comprehensive environmental impact assessments are conducted for all projects prior to 
their implementation to ascertain the level of potential environmental damage, the required mitigation measures to be put in place to minimize the adverse impact of energy projects and associated costs' [19]. While the ESIA process is designed to be robust and elaborate, poor application of ESIA procedures can contribute to poor potential conflict identification and prevention.

Whereas, ESIA process is not uniform from country to country, it generally consists of a set of procedural steps culminating in a written impact assessment statement that will inform the decision maker [23]. The process comprises of interactive steps such as screening, scoping, consideration of alternatives, action design, report preparation, report reviewing or evaluation, decision making, and post decision activities such as monitoring and auditing [24-25]. This article examines how conflict can be identified and addressed at an early stage during the ESIA process for energy projects. It is envisaged that a better understanding of the ESIA procedural steps that underpin conflict identification will be vital in successful execution of a proposed project.

\subsection{Statement of the problem}

Success in development of renewable energy resources in Kenya depends on various factors including identifying and addressing potential conflicts likely to arise during planning, development and implementation of such projects. ESIA is one of the tools that can be used to identify such potential conflict at an early stage. Appropriate potential conflict identification at the ESIA stage of any proposed renewable energy project is thus critical. Whereas it is generally accepted that ESIA procedures when appropriately applied can contribute to identify potential conflicts, ESIA stakeholders need to know which of the ESIA process steps are critical in underpinning conflict identification.

\subsection{Research objective}

The study objective was to establish which of the ESIA process steps can provide the most relevant insights for identification of potential conflicts for a proposed renewable energy project.

\subsubsection{Specific objectives}

1. To find out the perceptions of ESIA practitioners in Kenya on the effectiveness of EISA process steps in identifying potential conflicts from a proposed renewable energy project.

2. To statistically analyse the results of the first specific objective using cumulative odds ordinal logistic regression and compare findings with previous studies.

\section{LITERATURE REVIEW}

\subsection{The ESIA process}

The relevance of the social dimension of projects has increasingly been acknowledged, insomuch that new approaches to impact assessment have emerged [26]. This approach to impact assessment is ESIA that acknowledges, integrates, and evaluates environmental and social aspects of a project [26]. The ESIA approach to impact assessment is based on an integrated 
assessment of the multifaceted impact of projects, responding to the need to capture the complex and strong interrelationship linking land and society [26]. Key elements in the ESIA process are screening, scoping, impact analysis, mitigation, reporting, review, decision making, follow up and public participation [27]. Screening determines whether or not a proposal requires an ESIA, and if so, what level of analysis is necessary. This process brings clarity and certainty to the implementation of ESIA, ensuring that it neither entails excessive review nor overlooks proposals that warrant examination [28].

Scoping identifies the important issues in readiness for preparation of terms of reference; it is a critical, early step in the preparation of an ESIA [27]. The scoping process identifies the issues that are likely to be of most importance during the ESIA and eliminates those that are of little concern. In this way, ESIA studies are focussed on the significant effects, and time and money are not wasted on unnecessary investigations [29].

Impact analysis is carried out in the detailed phase of the ESIA; it involves identifying the impacts more specifically, predicting the characteristics of the main impacts and evaluating the significance of the residual impacts [27].

Mitigation is the stage of the ESIA process when measures are identified to avoid, minimize or remedy impacts. These measures are implemented as part of the process of impact management, together with any necessary adjustments to respond to unforeseen impacts. Both elements are integral to ensuring that the ESIA process leads to practical action to offset the adverse environmental and social impacts of proposed developments [27]. Mitigation recommends feasible and cost-effective measures to prevent or reduce significant negative impacts to acceptable levels [28].

Reporting involves compiling all the information obtained into an ESIA report document. It assembles the information that assists the proponent in managing the impacts of the proposal, the responsible authority in decision making and condition setting; and the public in understanding the likely impacts of the proposal [27]. The ESIA report should be comprehensive and must fulfil the requirement of the relevant ESIA regulation [29].

The review stage of the ESIA report is one of the main 'checks and balances' built into the ESIA process to establish the quality of an ESIA. It helps to ensure the information submitted is credible and sufficient for decision-making purposes [27] by verifying the accuracy and comprehensiveness of the report [29]. The decision-making element of the ESIA process involves approving or rejecting the proposal and setting conditions [28].

Decision-making stage provides for incorporation of environmental and social considerations into proposed development [29]. Once the proposed project is approved, implementation and follow up complete the ESIA process [27]. Monitoring, auditing and other tools are used to 'close the loop' of impact prediction and condition setting [30].

Monitoring and auditing is vital as it is used to identify the impacts that occur, to check that these are within the levels predicted and required by legislation, determine that mitigation measures are properly implemented and work effectively, ensure the environmental and social benefits expected are being achieved, and provide feedback to improve future applications of the ESIA process [31].

All the above processes and steps are tied together through a continuous public participation process, which has to be consultative, involving the public in an inclusiveness manner that ensures information sharing and transparency in order to influence outcome of decisions [32]. To contribute substantively in environmental decision making and environmental risk 
management, public participation should adhere to the established international best practice operating principles [33].

\subsection{Environmental conflicts and their impacts}

Conflicts can be defined as 'the interaction of interdependent people who perceive incompatible goals and interference from each other in achieving those goals' [34]. It is a perceived divergence of interests, or belief that the various stakeholders' current aspirations cannot be achieved simultaneously [35]. According to Tedeschi [36], a conflict is defined as 'an interactive state in which the behaviours or goals of one actor are to some degree incompatible with the behaviours or goals of some other actor or actors'. For a conflict to manifest, there has to be interdependence, differences in goals and differences in perceptions [37]. Conflicts emerge when stakeholders have irreconcilable differences or incompatible interests, values, power, perceptions and goals [38]. In a conflict situation, each party attempts to destroy, injure, thwart, influence or control the behaviour of another party [39].

Conflict situations are essentially bargaining situations in which the ability of one participant to achieve an intended goal is dependent to a large degree on the choices or decisions that the other participant will make [40]. Conflicts can be non-violent or violent but either can be damaging, results in withholding or cancellation of funding to a project or result in failed development [41]. Conflicts may disrupt economic activity, disrupt social activity, harm social relations and lead to property damage [42], or recognition of impending conflict can prompt change and progress [42]. An environmental conflict can manifest as political, social, economic, ethnic, religious, territorial strife or discontent over resources, or national interests [43]. Causes of such conflicts include unwillingness of State and governments to respond to the economic, social and political needs of those affected by the exploitation of natural resources, poor administration and distribution of proceeds from natural resources [44] and inadequate stakeholder participation in natural resource management policies, programmes and projects [45].

The importance of land in conflicts relates to people's ability to make a living or make a profit, land scarcity or ambiguous property rights which contribute to violent conflict [46], when land contains valuable mineral resources, conflicts can arise between local communities and those who seek control over land for resource extraction if the local community is not adequately consulted and fully involved in the exploitation of the resources [47]. Most conflicts are likely to emerge when a community or the public feel deprived of access to a resource, or development creates conditions that have socio-economic, cultural and environmental implications and likely to impact on their quality of life to a large extent [48].

Conflicts between the local people and the developers can affect efforts to exploit renewable energy resources. Olkaria geothermal field in Kenya has in the past been faced with land conflicts between the Maasai community and the government due to the latter allocating concessions to multinationals to develop the geothermal resource without first consulting the former and, secondly, compensating the former for the land [49]. Wind energy projects in Kenya, specifically, Kinangop wind energy project and Mpeketoni wind energy project, have been drawn into land conflicts that have resulted in court cancellation of the former and requirement to undertake a fresh ESIA [50] and land compensation row for the latter which has delayed project implementation [51]. 


\subsection{ESIA as a tool for conflict identification and prevention}

The importance of ESIA in conflict identification and prevention has been studied and analysed [41-42, 48]. The analyses are from different perspectives including social impact assessment [41], strategic impact assessment [41] and environmental impact assessment [48-49]. According to Prenzel and Vanclay [42], social impact assessment is capable of preventing conflicts by evaluating and managing negative social impacts, thus decreasing the conflict potential of a given project. Social impact assessment enables one to understand the circumstances and different positions and perceptions of stakeholders to promote equity and avoid conflicts [50]. Many environmental conflicts can be solved by means of ESIA [49].

ESIA is a valuable tool in conflict mediation as it helps to analyse the conflict and improve the mutual understanding of the parties involved in the conflict [48]. Methods of data collection employed in strategic impact assessment coupled with prediction of likely impacts and formulation of mitigation measures illustrate the potential of the assessment to prevent conflict [42]. Undertaking a social assessment from the perspective of the impacted stakeholders enables the assessor gain insights to potential conflict issues; the assessor's ability to address the mitigation of negative impacts and allows stakeholders to solve issues prior to project implementation and hence avert potential conflicts [50]. Through its ability of identifying underlying issues, strategic impact assessment becomes a valuable tool in conflict identification [51]. Furthermore, the tool also informs conflict management directly by evaluating the social impacts of the conflict management strategy to be implemented [51].

\section{METHODOLOGY}

\subsection{Study area}

The study area was the renewable energy sub-sector, specifically geothermal and wind energy. The study focussed on application of environmental and social impact procedures in the subsector.

\subsection{Study design and sampling procedure}

This research employed a descriptive research design where qualitative research methods were used to investigate research variables [52]. Sampling procedure used was simple random sampling. This sampling method observes the law of statistical regularity as it ensures same sample composition and characteristics for the chosen sample as the universe [52].

\subsection{Study variables and data collection procedures}

ESIA procedural steps namely project identification, screening, scoping, public participation, decision making, judicial review, project implementation and monitoring were the independent variables, whereas conflict identification was the dependent variable. The independent variables were polytomous, that is ordinal and categorical with three groups, whereas the dependent variable was ordinal, ordered and ranked on a five-point Likert scale. All variables addressed a specific research question as tabulated in Table 1. While all the variables were coded, the ordinal independent categorical variables were recoded (indicator variables) in order to correctly run a linear regression procedure in SPSS. The recoding took the form of 
Table 1: Study variables and research questions.

\begin{tabular}{|c|c|c|}
\hline Variable & Research question & Choice answers \\
\hline Project identification & $\begin{array}{l}\text { Can potential conflicts be identified } \\
\text { at the project identification stage of } \\
\text { EISA process? }\end{array}$ & $\begin{array}{l}\text { - Yes } \\
\text { - No } \\
\text { - I don't know }\end{array}$ \\
\hline Screening & $\begin{array}{l}\text { How relevant is the screening stage } \\
\text { of ESIA process in conflict identifi- } \\
\text { cation? }\end{array}$ & $\begin{array}{l}\text { - Very relevant } \\
\text { - Relevant } \\
\text { - Irrelevant }\end{array}$ \\
\hline Scoping & $\begin{array}{l}\text { How useful is the scoping stage of } \\
\text { ESIA process in conflict identifica- } \\
\text { tion? }\end{array}$ & $\begin{array}{l}\text { - Very useful } \\
\text { - Useful } \\
\text { - Not useful }\end{array}$ \\
\hline Public participation & $\begin{array}{l}\text { What form of public participation } \\
\text { during ESIA process is best in con- } \\
\text { flict identification? }\end{array}$ & $\begin{array}{l}\text { - Workshops } \\
\text { - Public meetings/bara- } \\
\text { za } \\
\text { - Public hearing }\end{array}$ \\
\hline Decision making & $\begin{array}{l}\text { What should inform the decision- } \\
\text { making stage of ESIA process for it } \\
\text { to be relevant in conflict identifica- } \\
\text { tion? }\end{array}$ & $\begin{array}{l}\text { - Project cycle } \\
\text { - Historical context } \\
\text { - Social context }\end{array}$ \\
\hline Project implementation & $\begin{array}{l}\text { At what stage of project implemen- } \\
\text { tation can potential conflicts be } \\
\text { identified? }\end{array}$ & $\begin{array}{l}\text { - Early } \\
\text { - Midway } \\
\text { - Towards the end }\end{array}$ \\
\hline Judicial review & $\begin{array}{l}\text { In your opinion, is judicial review } \\
\text { stage of ESIA process useful in } \\
\text { conflict identification? }\end{array}$ & $\begin{array}{l}\text { - Never useful } \\
\text { - Sometimes useful } \\
\text { - Always useful }\end{array}$ \\
\hline Monitoring & $\begin{array}{l}\text { When can potential conflicts be } \\
\text { identified at the monitoring stage of } \\
\text { the ESIA process? }\end{array}$ & $\begin{array}{l}\text { - Baseline monitoring } \\
\text { - Control monitoring } \\
\text { - Periodic monitoring }\end{array}$ \\
\hline Conflict identification & $\begin{array}{l}\text { How effective is ESIA in conflict } \\
\text { identification? }\end{array}$ & $\begin{array}{l}\text { - Very ineffective } \\
\text { - Ineffective } \\
\text { - Slightly effective } \\
\text { - Effective } \\
\text { - Very effective }\end{array}$ \\
\hline
\end{tabular}

indicator coding or effect cording. The number of indicator variables created for each categorical variable was one less than the number of its categories. Therefore, for each independent variable, the recoding generated two indicator variables, whereas for the dependent variable, the recoding generated four indicator variables.

\subsection{Data collection instrument}

A structured self-administered questionnaire with closed-ended multiple choice and Likert questions was used to collect data. Cronbach's alpha validity test was used to test for internal 
consistence (reliability) of the questionnaire items [53]. The questionnaire was administered to a sample of licenced ESIA practitioners in Kenya. Two hundred completed questionnaires were analysed $(n=200)$.

\subsection{Data analysis}

A cumulative odds ordinal logistic regression was used to determine the effect of each independent variable on the dependent variable [54]. In order to capture the ordered nature of the categories of the ordinal variables, the cumulative odds ordinal logistic regression with proportional odds, which uses cumulative categories, was used [55]. To ensure validity of the results obtained, the data were checked and tested to determine if it was in line with the four assumptions that are a prerequisite for ordinal regression namely (1) the dependent variable should be measured at the ordinal level, (2) one or more independent variables to be continuous, ordinal or categorical, (3) no multicollinearity and (4) each independent variable to have proportional odds. The data were checked for conformity to assumptions 1 and 2 based on the research design, while linear regression [56] and binomial logistic regression - a full likelihood ratio test comparing the fit of the proportional odds model to a model with varying location parameters [54-55] - were used to test conformity of the data to assumptions 3 and 4, respectively. All statistical analyses were performed using IBM SPSS Statistics Version 22. Interpretation of the findings from the ordinal regression was by indicating the relative odds of a higher level response, for the value of the explanatory variable under consideration, relative to its reference category.

3.6 Conformity of the data to the four assumptions required for an ordinal regression analysis

\subsubsection{Assumption 1: Ordinal dependent variable}

Dependent variable should be measured at the ordinal level. The requirement for assumption was met as the independent variables are ordinal and categorical.

\subsubsection{Assumption 2: Continuous, ordinal or categorical independent variables}

One or more independent variables to be continuous, ordinal or categorical. The requirement for this assumption was met as the dependent variable is ordinal, ordered and ranked as it is measured on a five-point Likert scale.

\subsubsection{Assumption 3: No multicollinearity}

This assumption requires that two or more independent variables should not be highly correlated with each other. When two or more independent variables are highly correlated with each other, then multicollinearity is said to have occurred [57]. In such a scenario, multicollinearity because problematic as it becomes difficult to understand which variable contributes to the explanation of the dependent variable and technical issues in calculating an ordinal logistic regression [57]. The coefficient table output of the SPSS linear regression test (Table 2) was used to determine if there is multicollinearity between two or more of the independent variables. The tolerance values or the Variance Inflation Factor (VIF) of the coefficients table determine if there is multicollinearity or not. When the tolerance value is less than 0.10 which equates to a VIF value of 10 or greater, then there is multicollinearity [57]. 
Table 2: Determination of multicollinearity between independent variables (coefficients ${ }^{\mathrm{a}}$ table for dependent variable conflict identification).

\begin{tabular}{lllc}
\hline \multicolumn{1}{c}{ Model } & \multicolumn{2}{c}{ Collinearity statistics } \\
& Tolerance & VIF \\
\hline $1 \quad$ I don't know & 0.80 & 1.23 \\
No & 0.93 & 1.07 \\
Irrelevant & 0.81 & 1.23 \\
Relevant & 0.86 & 1.16 \\
Not useful & 0.91 & 1.08 \\
Useful & 0.88 & 1.12 \\
Workshops & 0.84 & 1.17 \\
Public meetings/barazas & 0.84 & 1.18 \\
Project cycle & 0.41 & 2.41 \\
Historical context & 0.40 & 2.46 \\
Early & 0.14 & 6.98 \\
Midway & 0.14 & 7.06 \\
Never useful & 0.92 & 1.08 \\
Sometimes useful & 0.93 & 1.06 \\
Baseline monitoring & 0.94 & 1.05 \\
\hline
\end{tabular}

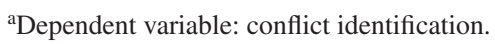

3.6.4 Assumption 4: Each independent variable to have proportional odds

This assumption requires that each independent variable to have an identical effect at each cumulative split of the ordinal dependent variable. This assumption is determined by comparing the model fit of the full likelihood ration test performed between two different cumulative odds models, that is test of parallel lines [58] (Table 3). The two models that are compared are the proportional odds model (the 'Null Hypothesis') and a cumulative odds model without the proportional odds constraint ('General'). When the assumption of proportional odds is said to be tenable, then the difference in model fit (the 'Chisquare') between these two models is small and not statistically significant $(p>0.05)$ [58]. When the assumption of proportional odds is said to have been violated, then the difference in model fit between these two models is large and statistically significant $(p<0.05)$.

\section{RESULTS}

\subsection{Linear regression}

There is no multicollinearity as the 'tolerance' values are greater than 0.10 (the lowest is 0.14) while the VIF values are less than 10 (the highest being 7.06) as shown in Table 2. 
Table 3: Comparison of the fit of the proportional odds model to a model with varying location parameters (model fit: test of parallel lines ${ }^{a}$ ).

\begin{tabular}{lllll}
\hline Model & $\mathbf{- 2}$ Log likelihood & Chi-square & df & Sig. \\
\hline Null hypothesis & 459.04 & & & \\
General & $407.82^{\mathrm{b}}$ & $51.22^{\mathrm{c}}$ & 48 & 0.34 \\
\hline
\end{tabular}

The null hypothesis states that the location parameters (slope coefficients) are the same across response categories.

aLink function: logit.

${ }^{\mathrm{b}}$ The log-likelihood value cannot be further increased after maximum number of step-halving.

${ }^{\mathrm{c}}$ The chi-square statistic is computed based on the log-likelihood value of the last iteration of the general model.

\subsection{Binomial logistic regression}

The assumption of proportional odds is tenable as assessed by a full likelihood ratio test comparing the fit of the proportional odds model to a model with varying location parameters, $\chi^{2}(48)=51.22, p=0.34$ as shown in Table 3 . By not violating this assumption, each independent variable is treated as having the same effect for each cumulative logit.

\subsection{Cumulative odds ordinal logistic regression}

4.3.1 Overall significance for each variable entered into the logistic regression model

The overall effect of public participation variable is statically significant, $\chi^{2}(2)=9.12$, $p=0.01$; likewise, the overall effect of the variable monitoring is statically significant, $\chi^{2}(2)$ $=6.29, p=0.04$ as shown in Table 4 .

Table 4: Model effects for variables entered into the logistic regression model.

\begin{tabular}{llll}
\hline \multicolumn{1}{c}{ Source } & Wald & Type III & \\
& chi-square & df & Sig. \\
\hline Project identification & 0.29 & 2 & 0.86 \\
Screening & 0.33 & 2 & 0.84 \\
Scoping & 0.27 & 2 & 0.87 \\
Public participation & 9.12 & 2 & 0.01 \\
Decision making & 4.88 & 2 & 0.08 \\
Judicial review & 3.54 & 2 & 0.17 \\
Project implementation & 4.74 & 2 & 0.09 \\
Monitoring & 6.29 & 2 & 0.04 \\
\hline
\end{tabular}

Dependent Variable: Conflict identification; Model: (Threshold), project identification, screening, scoping, public participation, decision making, judicial review, project implementation and monitoring. 
Table 5: Effect of each indicator variable for each polytomous variable in the logistic regression model.

\begin{tabular}{|c|c|c|c|c|c|c|c|c|}
\hline & Parameter & R & Hypoth & esis & & Exp. & $\begin{array}{l}95 \% \mathrm{~W} \\
\text { fidence } \\
\text { for Exp }\end{array}$ & $\begin{array}{l}\text { Id con- } \\
\text { nterval } \\
\text { (B) }\end{array}$ \\
\hline & tor & & $\begin{array}{l}\text { Wald } \\
\text { chi- } \\
\text { square }\end{array}$ & df & Sig. & & Lower & Upper \\
\hline $\begin{array}{l}\text { Thresh- } \\
\text { old }\end{array}$ & $\begin{array}{l}\text { [Conflict identification } \\
=0.00]\end{array}$ & -4.49 & 20.46 & 1 & 0.00 & 0.01 & 0.00 & 0.07 \\
\hline & $\begin{array}{l}\text { [Conflict identification } \\
=1.00]\end{array}$ & -3.10 & 10.52 & 1 & 0.00 & 0.04 & 0.00 & 0.29 \\
\hline & $\begin{array}{l}\text { [Conflict identification } \\
=2.00]\end{array}$ & -0.94 & 1.01 & 1 & 0.31 & 0.39 & 0.06 & 2.44 \\
\hline & $\begin{array}{l}\text { [Conflict identification } \\
=3.00]\end{array}$ & 0.42 & 0.20 & 1 & 0.64 & 1.53 & 0.024 & 9.54 \\
\hline [Public $\mathrm{p}$ & articipation $=0.00]$ & 1.93 & 9.12 & 1 & 000 & 6.93 & 1.97 & 24.35 \\
\hline [Public $\mathrm{p}$ & articipation $=1.00]$ & 0.34 & 1.28 & 1 & 0.25 & 1.41 & 0.077 & 2.58 \\
\hline [Public $\mathrm{p}$ & articipation $=2.00]$ & $0^{\mathrm{a}}$ & - & - & - & 1 & - & - \\
\hline [Decisio & making $=.00]$ & -0.35 & 0.76 & 1 & 0.38 & 0.70 & 0.31 & 1.55 \\
\hline [Decisio & making $=1.00]$ & -0.89 & 4.04 & 1 & 0.04 & 0.40 & 0.17 & 0.97 \\
\hline [Decisio & making $=2.00]$ & $0^{\mathrm{a}}$ & - & - & - & 1 & - & - \\
\hline [Project & mplementation $=0.00]$ & 1.03 & 3.64 & 1 & 0.05 & 2.81 & 0.97 & 8.17 \\
\hline [Project & mplementation $=1.00]$ & 0.46 & 1.71 & 1 & 0.19 & 1.58 & 0.79 & 3.14 \\
\hline [Project & mplementation $=2.00]$ & $0^{\mathrm{a}}$ & - & - & - & 1 & - & - \\
\hline [Monito & ing $=0.00]$ & -0.65 & 3.31 & 1 & 0.00 & 0.51 & 0.25 & 1.05 \\
\hline [Monito & ing $=1.00]$ & 1.23 & 2.44 & 1 & 0.11 & 3.42 & 0.73 & 16.04 \\
\hline [Monito & ing $=2.00]$ & $0^{\mathrm{a}}$ & - & - & - & 1 & - & - \\
\hline (Scale) & & $1^{\mathrm{b}}$ & & & & & & \\
\hline
\end{tabular}

Dependent variable: conflict identification. Model: (threshold), project identification, screening, scoping, public participation, decision making, judicial review, project implementation and monitoring.

${ }^{\text {aSet }}$ to zero because this parameter is redundant.

${ }^{b}$ Fixed at the displayed value.

\subsubsection{Effect of the independent variables on the dependent variable}

The variables public participation, decision making, project implementation and monitoring are statistically significant $\chi^{2}(1)=9.12, p=0.00 ; \chi^{2}(1)=4.04, p=0.04 ; \chi^{2}(1)=3.64, p=0.05$ and $\chi^{2}(1)=3.31, p=0.00$, respectively, as shown in Table 5 .

The coefficients in the parameter estimate (Table 5) show how each indicator variable of every polytomous variable differs on their effect on the dependent variable. The last category 
of each polytomous variable is used as the reference category. This means that the effect of the first two categories of each polytomous variable is separately compared to the reference category. Therefore, indicators variables of each of the identified statistically significantly polytomous variables are examined on how they differ by examining their odds ratio.

Results of the polytomous variable public participation show that there is an increase in the $\log$ odds of 1.93 of scoring higher on the dependent variable (conflict identification) when public participation is in the form of workshops compared to public hearing during ESIA process for renewable energy projects in Kenya. The change (difference) in terms of log odds (i.e. odds ratio) for the two indicator variables (workshops compared with public hearing) of the polytomous variable public participation is over three times. The odds ratio is the exponential of the log odds of the slope coefficient public participation $=00$ (workshops); that is, the exponential of 1.93 which is $\mathrm{e}^{1.93}=6.93$. This means that when engaging the public in workshops, the odds of scoring higher (being in a higher category) on the dependent variable (conflict identification) is over three times compared to when public participation is in public hearing during ESIA process for renewable energy projects in Kenya. Therefore, the odds ratio of being in a higher category of the dependent variable when public participation is in workshops compared to when it is in public hearings is 6.93 (95\% confidence interval [CI], 1.97-24.35), which is statistically significant, $\chi^{2}(1)=9.12, p=.00$. This means that when considering the variable public_participation, potential conflicts that could arise from implementation of a proposed renewable energy project are more likely to be identified at the ESIA process level when public participation is in workshops compared to when it is in a public hearing.

Considering the second coefficient of the variable public participation $=1.00$ (public meetings/barazas), the log odds of scoring higher on the dependent variable when public participation is in the form of public meetings (barazas) is of 0.34 compared to public hearing. The exponential of the log odds of the slope coefficient is 1.41 . However, there is no statistical significance when public participation is in public meetings (barazas) and when it is in public hearing as the odds ratio of being in a higher category of the dependent variable when public participation is in public meetings (barazas) compared to when it is in public hearings is 1.41 (95\% CI, 0.77-2.58), which is statistically insignificant, $\chi^{2}(1)=1.28, p=$ 0.25 . Considering the variable decision_making, the exponential of the log odds of the slope coefficient decision_making $=1.00$ (historical context), that is, the exponential of -.89 which is $\mathrm{e}^{-.89}=0.40$. Therefore for this variable the odds ratio of being in a higher category of the dependent variable when decision making is based on historical context compared to when it is based on social context is 1.41 (95\% CI, 0.77-2.58), which is statistically significant, $\chi^{2}(1)$ $=4.04, p=0.04$. That is to say, identifying potential conflicts (at ESIA stage) likely to result from a proposed renewable energy project is more likely when decision making is based on historical context than social context. However, there is no statistical significance when decision making based on project cycle is compared to social context as the odds ratio of being in a higher category of the dependent variable when decision making based on project cycle compared to social context is 0.70 (95\% CI, 0.31-1.55), which is statistically insignificant, $\chi^{2}(1)=0.76, p=0.38$.

\section{DISCUSSION}

The study results have shown that potential conflicts from proposed renewable energy projects are more likely to be identified at ESIA stage when stakeholder participation is in workshops as opposed to public meetings (baraza) and public hearings. The ultimate aim is 
to contribute to the facilitation of access to clean, reliable and affordable energy at the lowest level of the pyramid to generate income and improve quality of life [59]. Public participation, a constitutional and legislative requirement during ESIA process in Kenya [33], is an innovative way of bringing on board all those likely to be affected by an energy project decision to have an input into that decision using appropriate procedures [60]. Studies have shown that integration of energy end-user needs, sociocultural factors and local context in the overall energy project design avoid failed or ineffective energy project [59]. In this way local knowledge is exhaustively harnessed and incorporated in environmental decision making [33]. Interactive and collaborative public participation methods ensure that equal treatment is accorded to participants, public agencies, powerful private interests and disadvantaged citizens [61]. Interactive participation that adheres to best practices is an avenue for learning, conflicts resolution and new innovations [62]. Such result focussed public participation can only take place in a well-organized and structure setting that ensures appropriate facilitation of economically disadvantaged participants. Workshops are likely to achieve the interactive function among stakeholders which lacks in other form of participation including in the public hearing format [63]. This result concurs with previous studies that showed workshops method of consultation to be superior to other methods of public participation because they provide public input based on a relatively high level of information [63-64]. Further, workshops are more likely to follow best practices of public participation including focussing on negotiable issues; they have been documented as being effective in changing audience perceptions [65]. Workshops involve the public actively in the planning process; they bring the public and the planners together in serious working sessions; in this way the public is given sufficient information to make a meaningful input [63].

Forms of public participation used in Kenya during impact assessment such as public meetings (barazas) and public hearing are not effective in contributing substantively to environmental risk management [33]. Whereas workshops are generally structured, public meetings (baraza) and public hearing lack clear and well-documented guidelines and rules of engagement. This notwithstanding, public meetings (barazas) and public hearing are the legally recognized forms of public participation during ESIA process in Kenya [66-67]. Because of this, Omenge et al. [33] state that there is a need for legislative strengthening to seal existing loopholes and allow for a more elaborate standalone piece of legislation that spells out the nitty-gritties of public participation process. It is therefore argued that public participation in workshops in this research stood out as the best way of identifying potential conflicts during ESIA process in comparison to public hearing and public meetings because in workshops participants of different carder and social standing are accorded equal treatment and opportunity to contribute to the discussion. In this way pertinent issues are brought out for discussion in the process identifying potential areas of conflicts for negotiation and potential settlement. Now that stakeholder engagement in workshops has been identified as being more likely to identify potential conflicts from development of an energy resource project, it is argued that well-structured, coordinated and comprehensive stakeholder interactions in workshops during ESIA stage of the development of energy resources will contribute to addressing the documented policy challenge of 'inadequate government driven mechanisms for addressing and responding to conflicts and social unrests surrounding exploitation of energy resources' [19]. Public participation in workshops during ESIA process for energy projects could be a step in the direction of implementation of energy policy strategy that require 'government to develop and implement a monitoring and evaluation mechanism on regular reporting on stakeholder's consultations' [19]. Thorough active consultation and 
participation of the public during ESIA is more likely to be achieved in workshops, which will eventually address what has otherwise been seen as a weak aspect of the impact assessment process [29].

\section{CONCLUSIONS}

The current forms of public participation (public meetings/barazas and public hearings) during ESIA process in Kenya have been used for over a decade and half. There is no doubt that these forms of public participation have contributed to improving public awareness and participation on matters environmental. However, as the public become more and more aware on matters environment, their obligation and rights, new challenges keep emerging. One of the challenges brought about by the increased awareness is disagreements and/or conflicts among stakeholders on a proposed development action. The current forms of public participation in environmental decision-making process do not have the capacity to address this challenge effectively and hence the need to change tactic. Addressing this challenge will ensure that public participation during ESIA process is not just done to fulfil a process and legal requirement (as currently is the case) but most importantly to contribute to informing decision making by identifying potential conflicts likely to occur from implementation of a proposed project. This can be done by actively engaging stakeholders in structure dialogue in workshops where adequate information is disseminated for the stakeholder to make a meaningful contribution that can lead to identification of a potential conflict. Workshops for many decades have been identified and effectively used in constructive and result oriented stakeholder participation. It is high time now for workshops to replace existing forms of public participation. Workshops therefore should be formerly entrenched and recognized legislatively as a form of stakeholder participation during ESIA process.

In order for public consultation during ESIA process to be done in workshops as opposed to public meetings (barazas) and public hearing as currently is the case, there is a need to legally underpinning workshops as a mandatory form of public participation during ESIA process. To achieve this, a review of the current legislations more specifically the Environmental (Impact Assessment and Audit) Regulations, 2003 and the proposed Draft Environmental (Strategic Assessment, Integrated Impact Assessment and Audit) Regulations needs to be done. But most important is the development of a standalone piece of legislation on public participation during ESIA process in Kenya that includes workshops as one of the mandatory forms of public participation. While this research has identified vital EISA procedural steps that underpin conflict identification, there is great value in understanding the social, cultural and context-specific attributes of the sources of conflict and opposition. Thus in the ESIA process, it is not enough to identify the steps where there is good potential for new insights, but we must strive to design the ESIA process in such a way that some normative advice can emerge from the process and help develop pathways for proponents of projects and the community to find common ground. This is an area that requires further research.

\section{ACKNOWLEDGEMENTS}

We thank the Waterloo Institute for Sustainable Energy (WISE) University of Waterloo Canada for funding support, the International Support Network for African Development (ISNAD-Africa) for mentorship, ESIA Practitioners in Kenya for responding to the questionnaire survey and the Research Assistants who helped follow-up and collect questionnaires. 


\section{REFFERENCES}

[1] Moomaw, W., Yamba, F., Kamimoto, M., Maurice, L., Nyboer, J., Urama, K. \& Weir, T., Introduction. IPCC Special Report on Renewable Energy Sources and Climate Change Mitigation, eds. O. Edenhofer, R. Pichs-Madruga, Y. Sokona, K. Seyboth, P. Matschoss, S. Kadner, T. Zwickel, P. Eickemeier, G. Hansen, S. Schlömer, C.von Stechow, Cambridge University Press: Cambridge, UK and New York, NY, USA, 2011.

[2] Demirbaş, A., Global renewable energy resources. Energy Sources, 28(8), pp. 779-792, 2006. https://doi.org/10.1080/00908310600718742

[3] Fridleifsson, I.B., Geothermal energy for the benefit of the people. Renewable and Sustainable Energy Reviews, 5(3), pp. 299-312, 2001. https://doi.org/10.1016/s13640321(01)00002-8

[4] Nathwani, J. \& Kammen, D.M., Affordable energy for humanity: a global movement to support universal clean energy access. Proceedings of the IEEE, 107(9), pp. 1780 1789, 2019. https://doi.org/10.1109/jproc.2019.2918758

[5] Tsoutsos, T., Frantzeskaki, N. \& Gekas, V., Environmental impacts from the solar energy technologies. Energy Policy, 33(3), pp. 289-296, 2005. https://doi.org/10.1016/ s0301-4215(03)00241-6

[6] Asif, M. \& Muneer, T., Energy supply, its demand and security issues for developed and emerging economies. Renewable and Sustainable Energy Reviews, 11(7), pp. 13881413, 2007. https://doi.org/10.1016/j.rser.2005.12.004

[7] Cañizares, C., Nathwani, J. \& Kammen, D., Electricity for all: issues, challenges, and solutions for energy-disadvantaged communities. Proceedings of the IEEE, 107(9), pp. 1775-1779, 2019. https://doi.org/10.1109/jproc.2019.2935856

[8] Kazimierczuk, A.H., Wind energy in Kenya: A status and policy framework review. Renewable and Sustainable Energy Reviews, 107, pp. 434-445, 2019. https://doi. org/10.1016/j.rser.2018.12.061

[9] Dalla Longa, F. \& van der Zwaan, B., Do Kenya's climate change mitigation ambitions necessitate large-scale renewable energy deployment and dedicated low-carbon energy policy? Renewable Energy, 113, pp. 1559-1568, 2017. https://doi.org/10.1016/j. renene.2017.06.026

[10] Kiplagat, J.K., Wang, R.Z. \& Li, T.X., Renewable energy in Kenya: Resource potential and status of exploitation. Renewable and Sustainable Energy Reviews, 15(6), pp. 2960-2973, 2011.

[11] Kenya National Bureau of Statistics. Statistical Abstract, ISBN: 978-9966-102-07-2, 2018. https://doi.org/10.1016/j.rser.2011.03.023

[12] International Renewable Energy Agency (IRENA), Renewable capacity statistics, Abu Dhabi, ISBN 978-92-9260-123-2, 2019.

[13] Kinga, F.W. \& Kwasira, J., Analysis of the environmental impacts of geothermal drilling on livelihoods of adjacent communities in Menengai geothermal power project. Journal of Environmental Science, Toxicology and Food Technology, 10(4), pp. 71-76, 2016. https://doi.org/10.35942/ijcab.v3ivi.89

[14] Energy and Petroleum Regulatory Authority (EPRA), https://renewableenergy.go.ke/ index.php/content/28, accessed 28 October 2019.

[15] Solarplaza Facts and Figures, Solar Energy 2019, www.africa.unlockingsolarcapital. com, accessed 21 May 2019. 
[16] Ministry of Energy. Wind Sector Prospectors - Kenya: Wind Energy data analysis and development programme, https://www.renewableenergy.go.ke/asset_uplds/files/Wind $\% 20$ Sector\%20Prospectus\%20Kenya.pd, accessed last on 28 October 2019.

[17] WorldRemit, https://www.standardmedia.co.ke/business/article/2001353188/uhurulaunches-sh13b-solar-power-plant, accessed 23rd December 2019.

[18] Dahir, A.L., 2019. https://qz.com/africa/1671484/kenya-opens-africas-largest-windpower-project-in-turkana/ accessed 23rd December 2019.

[19] Government of Kenya, National Energy Policy, Ministry of Energy, 2018.

[20] Manring, N., West, P.C. \& Bidol, P., Social impact assessment and environmental conflict management: potential for integration and application. Environmental Impact Assessment Review, 10(3), pp. 253-265, 1990. https://doi.org/10.1016/0195-9255(90)90041-w

[21] Prenzel, P.V. \& Vanclay, F., How social impact assessment can contribute to conflict management. Environmental Impact Assessment Review, 45, pp. 30-37, 2014.

[22] Government of Kenya, Sessional Paper No. 4 on Energy, Ministry of Energy, 2004.

[23] Worldwide EL, Guidebook for evaluating mining project EIAs, Environmental Law Alliance Worldwide, Eugene, Oregon, 2010.

[24] Glasson, J. \& Therivel, R., Introduction to Environmental Impact Assessment, Routledge, 2013.

[25] Government of Kenya, National Environmental Policy, 2013.

[26] Dendena, B. \& Corsi, S., The environmental and social impact assessment: a further step towards an integrated assessment process. Journal of Cleaner Production, 108, pp. 965-977, 2015. https://doi.org/10.1016/j.jclepro.2015.07.110

[27] Sadler, B. \& McCabe, M., Environmental impact assessment training resource manual, UNEP Division of Technology, Industry Economics and Trade Branch, 2002.

[28] Government of Kenya, Environment Impact Assessment Guidelines and Administrative Procedures, 2002.

[29] Glasson, J., Therivel, R. \& Chadwick, A., Introduction to Environmental Impact Assessment, Fourth Edition, Milton Park, Abingdon, Oxon, 2012.

[30] Sadler, B., International study of the effectiveness of environmental assessment: final report, International Association for Impact Assessment and Canadian Environmental Assessment Agency, Ministry of Supply and Services, Ottawa, 1996.

[31] Arts EJ. EIA-follow up: on the role of ex post evaluation in environmental impact assessment, University of Groningen, 1998.

[32] André, P., Enserink, B., Connor, D. \& Croal, P., Public participation international best practice principles, Special publication series, 4, International Association for Impact Assessment, Fargo, USA, 2006.

[33] Omenge, P.M, Eshiamwata, G.W, Makindi, S.M. \& Obwoyere, G.O., Public participation in environmental impact assessment (EIA) and its substantive contribution in environmental risk management: Insights from EIA practitioners and other stakeholders in Kenya's renewable energy projects. WIT Transaction on Ecology and the Environment, 237, pp. 133-144, WIT Press, 2019.

[34] Folger, J., Poole, M.S. \& Stutman, R.K. Working through conflict: Strategies for relationships, groups, and organizations. Routledge, 2017.

[35] Pruitt Dean, G. \& Kim, S.H., Social Conflict: Escalation, Stalemate and Settlement, McGraw-Hill Education, 4th ed., 2004.

[36] Tedeschi, J.T., Conflict, Power, and Games: The Experimental Study of Interpersonal Relations, Routledge, 2017. 
[37] Wall Jr., J.A. \& Callister, R.R., Conflict and its management. Journal of management, 21(3), pp. 515-558, 1995. https://doi.org/10.1177/014920639502100306

[38] Castro, A.P. \& Nielsen, E., eds., Natural Resource Conflict Management Case Studies: an Analysis of Power, Participation and Protected Areas, Food and Agriculture Organization of the United Nations, Rome, 2003.

[39] Sidaway, R., Outdoor Recreation and Nature Conservation: Conflicts and their Resolution, Doctoral Thesis, The University of Edinburgh, 1996.

[40] Schelling, T.C., The strategy of conflict. Prospectus for a reorientation of game theory. Journal of Conflict Resolution, 2(3), pp. 203-264, 1958. https://doi. org/10.1177/002200275800200301

[41] Barrow, C.J., How is environmental conflict addressed by SIA? Environmental Impact Assessment Review, 30(5), pp. 293-301, 2010. https://doi.org/10.1016/j. eiar.2010.04.001

[42] Prenzel, P.V. \& Vanclay, F., How social impact assessment can contribute to conflict management. Environmental Impact Assessment Review, 45, pp. 30-37, 2014. https:// doi.org/10.1016/j.eiar.2013.11.003

[43] Libiszewski, S. \& Spillmann, K., Environment and Conflicts Project ENCOP Occasional Papers, Center for Security Studies ETH Zurich and Swiss Peace Foundation, chapter What is Environmental Conflict, 1995.

[44] Lujala, P., Gleditsch, N.P. \& Gilmore, E., A diamond curse? Civil war and a lootable resource. Journal of Conflict Resolution, 49(4), pp. 538-562, 2005. https://doi. org/10.1177/0022002705277548

[45] Castro, A.P. \& Nielsen, E., eds., Natural resource conflict management case studies: an analysis of power, participation and protected areas, Food and Agriculture Organization of the United Nations, Rome, 2003.

[46] Bob, U., Land-related conflicts in sub-Saharan Africa. African Journal on Conflict Resolution, 10(2), 2010.

[47] Kok, A., Lotze, W. \& Van Jaarsveld, S., Natural resources, the environment and conflicts, African Centre for the Constructive Resolution of Disputes (ACCORD), 2009. https://doi.org/10.4314/ajcr.v10i2.63310

[48] Hellström, E., Conflict cultures - qualitative comparative analysis of environmental conflicts in forestry, Silva Fennica Monographs 2. Helsinki, The Finnish Society of Forest Science and The Finnish Research Institute, 2001.

[49] Koissaba, B.O., Campaign Update: Kenya- Maasai protest against new land concessions for geothermal extraction in Kenya, https://www.culturalsurvival.org/ news/ campaign-update-kenya-maasai-protest-against-new-land-concessions-geothermalextraction-kenya, accessed 29th October 2019.

[50] Damary, R., Court stops Kinangop's Sh15bn wind power plant, https://www.the-star. co.ke/news/2016-04-02-court-stops-kinangops-sh15bn-wind-power-plant/, accessed 29 October 2019.

[51] Ougo, M., Mpeketoni wind power project faced with compensation row, http://mediamaxnetwork.co.ke/k24-tv/compensation-row-looms-over-proposed-90mw-windpower-project-in-mpeketoni-214767/ accessed 29 October 2019.

[52] Kothari, C.R., Research Methodology: Methods and techniques, New Age International, 2004.

[53] Yu, C.H., An introduction to computing and interpreting Cronbach coefficient alpha in SAS. Proceedings of the 26th SAS User Group International Conference, SAS Institute Inc., Cary, NC, 2001. 
[54] Agresti, A., Analysis of Ordinal Categorical Data, John Wiley \& Sons, 2010.

[55] McCullagh, P., Regression models for ordinal data. Journal of the Royal Statistical Society: Series B (Methodological), 42(2), pp. 109-127, 1980. https://doi.org/ 10.1111/j.2517-6161.1980.tb01109.x

[56] Weisberg, S., Applied Linear Regression, John Wiley \& Sons, 2005.

[57] Midi, H., Sarkar, S.K. \& Rana, S., Collinearity diagnostics of binary logistic regression model. Journal of Interdisciplinary Mathematics, 13(3), pp. 253-267, 2010. https://doi. org/10.1080/09720502.2010.10700699

[58] Norris, C.M., Ghali, W.A., Saunders, L.D., Brant, R., Galbraith, D., Faris, P. \& Knudtson, M.L., APPROACH Investigators. Ordinal regression model and the linear regression model were superior to the logistic regression models. Journal of Clinical Epidemiology, 59(5), pp. 448-456, 2006. https://doi.org/10.1016/j.jclinepi.2005.09.007

[59] Clements, A., Wheeler, S., Mohr, A. \& McCulloch, M., The service value method for design of energy access systems in the global south. Proceedings of the IEEE, 107(9), pp. 1941-1966, 2019. https://doi.org/10.1109/jproc.2019.2901215

[60] Rowe, G. \& Frewer, L.J., Public participation methods: a framework for evaluation. Science, Technology, \& Human Values, 25(1), pp. 3-29, 2000. https://doi.org/ 10.1177/016224390002500101

[61] Innes, J.E. \& Booher, D.E., Reframing public participation: strategies for the 21 st century. Planning Theory \& Practice, 5(4), pp. 419-436, 2004. https://doi.org/10.1080/14 64935042000293170

[62] Connick, S. \& Innes, J.E., Outcomes of collaborative water policy making: Applying complexity thinking to evaluation. Journal of Environmental Planning and Management, 46(2), pp. 177-197, 2003. https://doi.org/10.1080/0964056032000070987

[63] Heberlein, T.A., Some observations on alternative mechanisms for public involvement: The hearing, public opinion poll, the workshop and the quasi-experiment. Natural. Resources Journal, 16, paper 197, 1976.

[64] Borton, T.E. \& Warner, K.P., Involving citizens in water resources planning: The communication-participation experiment in the Susquehanna River Basin. Environment and Behavior, 3(3), pp. 284-306, 1971. https://doi.org/10.1177/001391657100300304

[65] McKenney, C. \& Terry, R., The effectiveness of using workshops to change audience perception of and attitudes about xeriscaping. HortTechnology, 5(4), pp. 327-329, 1995. https://doi.org/10.21273/horttech.5.4.327

[66] Government of Kenya, the Environmental Management and Co-ordination (Amendment) Act, 2015, Kenya Gazette Supplement No. 74, Acts No. 5, 2015.

[67] Government of Kenya, Environmental (Impact Assessment and Audit) Regulations, Legal Notice No. 101, Kenya Gazette Supplement No. 56, Legislative Supplement No. 31, 2003. 